\title{
Spring Wheat Tolerance and Resistance to Heterodera avenae in the Pacific Northwest
}

Richard W. Smiley, Columbia Basin Agricultural Research Center, Oregon State University, Pendleton; Juliet M. Marshall, Cereals Research and Extension Program, University of Idaho, Idaho Falls 83402; Jennifer A. Gourlie, Columbia Basin Agricultural Research Center, Oregon State University; Timothy C. Paulitz, United States Department of Agriculture-Agricultural Research Service (USDAARS) Root Disease and Biological Control Unit, Washington State University, Pullman 99164; Shyam L. Kandel, Department of Plant Pathology, and Michael O. Pumphrey, Department of Crop and Soil Sciences, Washington State University, Pullman; Kimberly Garland-Campbell, USDA-ARS Wheat Genetics, Quality, Physiology, and Disease Research Unit, Washington State University, Pullman; Guiping Yan, Columbia Basin Agricultural Research Center, Oregon State University; Monte D. Anderson, Bayer CropScience, Spangle, WA 99031; Michael D. Flowers, Department of Crop and Soil Science, Oregon State University, Corvallis 97331; and Chad A. Jackson, Cereals Research and Extension Program, University of Idaho, Aberdeen 83210

\begin{abstract}
Smiley, R. W., Marshall, J. M., Gourlie, J. A., Paulitz, T. C., Kandel, S. L., Pumphrey, M. O., Garland-Campbell, K., Yan, G. P., Anderson, M. D., Flowers, M. D., and Jackson, C. A. 2013. Spring wheat tolerance and resistance to Heterodera avenae in the Pacific Northwest. Plant Dis. 97:590600 .

The cereal cyst nematode Heterodera avenae reduces wheat yields in the Pacific Northwest. Previous evaluations of cultivar resistance had been in controlled environments. Cultivar tolerance had not been evaluated. Seven spring wheat trials were conducted in naturally infested fields in three states over 2 years. A split-plot design was used for all trials. Five trials evaluated both tolerance and resistance in 1.8-by-9-m plots treated or not treated with nematicides. Two trials evaluated resistance in 1-m head rows where each wheat entry was paired with an adjacent row of a susceptible cultivar. Cultivars with the Crel resistance gene ('Ouyen' and 'Chara') reduced the postharvest density of

H. avenae under field conditions, confirming Crel parents as useful for germplasm development. Ouyen was resistant but it was also intolerant, producing significantly lower grain yield in controls than in plots treated with nematicides. Susceptible cultivars varied in tolerance. Undefined resistance was identified in one commercial cultivar ('WBRockland) and four breeding lines (UC1711, SO900163, SY-B041418, and SY-97621-05). This research was the first systematic field demonstration of potential benefits to be derived through development and deployment of cultivars with resistance plus tolerance to cereal cyst nematode in North America.
\end{abstract}

Wheat (Triticum aestivum L.) is planted on 1.7 million ha annually in the Pacific Northwest (PNW) states of Idaho, Oregon, and Washington (58). The cereal cyst nematode Heterodera avenae Woll. infests soils of localized regions throughout the PNW $(19,25,44,55)$. This nematode reduces grain yield of spring wheat and winter wheat under both rainfed and irrigated conditions $(47,52)$. The annual impact on wheat production was estimated to be nearly 21,000 tons valued at $\$ 3.4$ million (44). Yields of barley and oat are also reduced on fields infested by $H$. avenae $(24,49)$. Invasion of roots by this nematode reduces rooting depth, often leading to greater damage to plants on rainfed than on irrigated fields because maturing plants on rainfed fields rely upon extraction of water from deep in the soil profile (5). In all, $80 \%$ of wheat in the PNW is produced under rainfed conditions and $20 \%$ receives supplemental irrigation. Most annual rainfall occurs from late autumn through early spring and the summers become very warm and dry long before the wheat matures. Mean annual rainfall in the primary wheat-producing areas varies from about 250 to $600 \mathrm{~mm}$ (41).

Practices recommended for managing the impacts of cereal cyst nematode are currently limited (49) and are generally not profitable for wheat producers in the PNW. These practices include long rotations utilizing multiple years of broadleaf crops or bare fallow (47). No chemical or biological nematicides are currently available to manage $H$. avenae (44). Development of cultivars with

Corresponding author: R. Smiley, E-mail: richard.smiley@oregonstate.edu

Accepted for publication 28 November 2012.

http://dx.doi.org/10.1094/PDIS-10-12-0906-RE

(C) 2013 The American Phytopathological Society genetic resistance plus genetic tolerance has been advocated internationally for many decades $(5,18,35,49)$ but this has not yet been achieved in the PNW.

Wheat cultivars with both resistance and tolerance are required for optimal performance in existing plantings (e.g., tolerance) as well as for reducing the future risk (e.g., resistance) to subsequent plantings of intolerant cultivars or crops. Cultivars that greatly suppress or prevent reproduction of nematodes are classed as resistant and those that allow moderate to high rates of reproduction are susceptible (13). Resistance to $H$. avenae in the PNW has been reported from controlled-environment studies (53) but the stability of that resistance has not been examined under field conditions in North America, and the potential benefit of growing a resistant cultivar in naturally infested fields has also not been demonstrated.

Cultivars having an ability to withstand or recover from nematode invasion and to yield well in comparison with noninvaded plants are characterized as tolerant and those that are sensitive and exhibit a significantly suppressed yield when invaded are characterized as intolerant (13). Tolerance is more difficult to assess and increases with plant age (18). Tolerance is usually estimated in the field by comparing the yield of a specific plant cultivar in a naturally infested soil that is either left untreated or is treated with a nematicide such as aldicarb to reduce the impact of the existing nematode population $(10,20,45,46,57)$. It is also possible but generally impractical to examine tolerance by inoculating portions of fields to compare growth in adjacent highly and noninfested plots. Likewise, it is possible to compare plant growth and yield in nearby fields that are either infested or not infested by $H$. avenae (54), or to create contrasting densities of $H$. avenae in adjacent blocks by producing nonhost and host crops for multiple years (38). In each of the latter cases, care must be taken to avoid accompanying changes in the inoculum density of soilborne fungal 
pathogens. Potential differences in tolerance in resistant as well as in susceptible genotypes had not been evaluated in North America.

Over 2 years and three locations, we evaluated the field tolerance and resistance of an imported Australian spring wheat cultivar ('Ouyen') that had been shown to exhibit resistance to PNW populations of $H$. avenae under controlled conditions (53). In a single year at three locations, we also evaluated Turkish 'Sönmez' that was reported to be resistant to $H$. filipjevi (40) but had not been evaluated against $H$. avenae. At two locations during a single year, we evaluated tolerance and resistance characteristics of $20 \mathrm{PNW}$ spring wheat cultivars that were considered to be of highest priority to the wheat industry. Finally, in two single-year, single-location trials, we evaluated resistance characteristics for 40 advanced breeding lines entered into the 2012 Western Regional Hard and Soft Spring Wheat Nurseries, and 24 additional lines selected from imported and domestic sources.

\section{Materials and Methods}

Locations. Spring wheat trials were performed over a 2-year period on seven commercial fields at six PNW locations. Characteristics of trial sites and dates for important trial management activities are shown in Table 1 . The Idaho site is characterized by a continental, semiarid climate with cold winters and warm, dry summers. Oregon and Washington locations are characterized by Mediterranean, semiarid climates having cool, moist winters and warm, dry summers. All fields were selected based on previous knowledge that they were infested by $H$. avenae, for which the pre-plant or early-season density in soil is shown in Table 1. Both tolerance and resistance were evaluated in five trials conducted at four locations in Idaho, Oregon, and Washington. Two resistance trials were at additional locations in Washington. Trials in Idaho were performed in a different field each year.
Nematode density and identification. Pre-plant density of plant-parasitic nematode genera in each experimental area was determined by collecting two composite soil samples per experimental area at the time of planting or within 2 weeks before planting (Table 1). Each composite sample consisted of 25 soil cores of $2.5 \mathrm{~cm}$ in diameter by $30 \mathrm{~cm}$ in depth. The samples were submitted to Western Laboratories for extraction and enumeration of nematodes. The lab uses a modified Oosterbrink elutriator extraction method, described in greater detail by Smiley et al. (48). Briefly, vermiform and encysted life stages were extracted and collected on separate sieves. Cysts were broken mechanically to extract eggs and larvae and the suspension was added to the suspension of vermiform life stages present in the soil. The suspension was then concentrated through multiple sequences of centrifugation and density flotation using a magnesium sulfate solution. Western Laboratories reported numbers of plant-parasitic nematodes that were identified to the genus level.

Heterodera and Pratylenchus spp. extracted from samples at each location were identified during previous research and during surveys of the new experimental areas $(52,53,61,62)$. Briefly, these species were identified using combinations of morphological and molecular methods (61-63). For Heterodera spp., key morphological features for cysts examined under a compound light microscope included color, underbridge in the vulval cone, semifenestrae shape, and development of bullae. DNA was extracted from cysts and examined using polymerase chain reaction (PCR) restriction fragment length polymorphism (RFLP) procedures (61). The PCR products were digested with six restriction endonucleases (TaqI, HinfI, PstI, HaeIII, RsaI, and AluI) and the species of Heterodera was determined by comparing the restriction pattern with those of nine pure Heterodera control species ( $H$. avenae, $H$. filipjevi, $H$. latipons, and $H$. schachtii) in agarose gels by electrophoresis.

Table 1. Sites and summary of field operations where spring wheat cultivars were evaluated in seven naturally infested fields for resistance or tolerance to Heterodera avenae in the Pacific Northwest during 2011 and 2012

\begin{tabular}{|c|c|c|c|c|c|c|c|}
\hline \multirow[b]{2}{*}{ Variables } & \multicolumn{2}{|c|}{ Idaho } & \multirow{2}{*}{$\begin{array}{c}\text { Oregon } \\
2011\end{array}$} & \multicolumn{4}{|c|}{ Washington } \\
\hline & 2011 & 2012 & & 2011 & 2012 & 2011 & 2012 \\
\hline Site designation & St. Anthony & St. Anthony & Cove & Steptoe & Cashup & Pullman & Colton \\
\hline County & Fremont & Fremont & Union & Whitman & Whitman & Whitman & Whitman \\
\hline Nearest city & Rexburg & Rexburg & La Grande & Colfax & Colfax & Pullman & Colton \\
\hline Latitude (N) & $43.922^{\circ}$ & $43.919^{\circ}$ & 45.312 & 47.013 & 47.065 & 46.769 & 46.565 \\
\hline Longitude (W) & -111.638 & -111.638 & -117.859 & -117.357 & -117.386 & -117.273 & -117.114 \\
\hline Altitude (m) & 1,521 & 1,521 & 822 & 712 & 709 & 755 & 776 \\
\hline Precipitation $(\mathrm{mm})^{\mathrm{r}}$ & 352 & 352 & 380 & 509 & 505 & 533 & 533 \\
\hline Soil series name & St. Anthony & St. Anthony & Hot Lake & Caldwell & Covello & Latah & Covello \\
\hline Soil textures & gsal & gsal & Silt loam & Silt loam & Silt loam & Silt loam & Silt loam \\
\hline Water & Rainfed & Rainfed & Irrigated & Rainfed & Rainfed & Rainfed & Rainfed \\
\hline Cropping $^{t}$ & $\mathrm{~W} / \mathrm{F}$ & $\mathrm{W} / \mathrm{P}$ & $\mathrm{AW}$ & AW & $\mathrm{AW}$ & WW/SW/SL & WW/SW/SL \\
\hline Previous crop & SW & $\mathrm{P}$ & WW & SW & WW & SW & SW \\
\hline Wheat entries in trial & 4 & 20 & 4 & 4 & 20 & 24 & 40 \\
\hline Replicates in trial & 6 & 6 & 6 & 6 & 6 & 8 & 8 \\
\hline Goal $^{\mathrm{u}}$ & $\mathrm{T} \& \mathrm{R}$ & $\mathrm{T} \& \mathrm{R}$ & $\mathrm{T} \& \mathrm{R}$ & $\mathrm{T} \& \mathrm{R}$ & $\mathrm{T} \& \mathrm{R}$ & $\mathrm{R}$ & $\mathrm{R}$ \\
\hline Planting date & 28 April & 11April & 6 May & 11 May & 11 May & 17 May & 11 May \\
\hline Nematode $\mathrm{Pi}^{\mathrm{v}}$ & 28 April & 6 April & 20 May & 11 May & Feb 28 & 28 June & 4 April 2011 \\
\hline H. avenae ${ }^{\mathrm{w}}$ & 6.7 & 5.8 & 2.9 & 2.3 & 2.9 & 3.8 & 4.3 \\
\hline Root sampling ${ }^{\mathrm{x}}$ & 20 June & 25 June & 6 July & 8 August & 11 July & 14 July & 8 July \\
\hline Harvest date & 21 September & 10 August & 21 September & 22 September & 30 August & $n a^{y}$ & na \\
\hline Nematode $\mathrm{Pf}^{\mathrm{z}}$ & 26 September & 10 August & 3 October & 12 October & 30 August & na & na \\
\hline
\end{tabular}

${ }^{\mathrm{r}}$ Mean annual precipitation.

s Soil: gsal = gravelly sandy loam.

${ }^{\mathrm{t}}$ All fields were cultivated between crops except for the Steptoe, WA site that was planted directly into wheat stubble without tillage. W/F = wheat-fallow rotation, $\mathrm{W} / \mathrm{P}=$ wheat-potato rotation, $\mathrm{AW}=$ annual wheat, $\mathrm{P}=$ potato, $\mathrm{SL}=$ spring legume, $\mathrm{SW}=\mathrm{spring}$ wheat, and $\mathrm{WW}=$ winter wheat.

${ }^{\mathrm{u}}$ Goal of experiment: $\mathrm{T}=$ tolerance and $\mathrm{R}=$ resistance.

${ }^{v}$ Date on which initial nematode density was determined from soil samples collected to 30- to 45-cm depths across the experimental areas prior to or immediately following planting.

${ }^{\text {w }}$ Mean preplant density of $H$. avenae eggs + second-stage juveniles per gram of soil for two samples (25 cores of 2.5 -cm diameter and $30-\mathrm{cm}$ depth were composited for each sample) taken from each half of each experimental area.

${ }^{x}$ Date on which root samples were collected for evaluations of root knotting symptoms or numbers of swollen white females of $H$. avenae produced on each plant.

y Not applicable.

${ }^{\mathrm{z}}$ Date on which the postharvest nematode density was determined in soil collected directly below wheat rows. Samples consisted of a composite of 20 soil cores/plot; 2.5 -cm diameter by $30-\mathrm{cm}$ depth. 
Identification of Pratylenchus spp. was made by examining features such as vulval position and tail shape and by examining DNA of nematodes extracted from soil. The PCR band patterns were compared with those of DNA from 25 pure nematode control cultures (Pratylenchus neglectus, $P$. thornei, $P$. agilis, $P$. crenatus, P. zeae, P. scribneri, P. penetrans, Meloidogyne chitwoodi, M. hapla, $M$. naasi, $H$. avenae, $H$. filipjevi, a Tylenchorhynchus sp., Merlinius brevidens, a Paratylenchus sp., and "background" nonplant-parasitic species). Stunt nematode genera detected at some of the trial locations were not identified to species. Previous experience and surveys $(19,51)$ have shown that these nematodes were likely to be mixtures of Tylenchorhynchus (mostly Tylenchorhynchus clarus) and $M$. brevidens (=Geocenamus brevidens).

Postharvest nematode densities in the five tolerance and resistance experiments (Table 1) were determined by collecting samples consisting of a composite of 20 soil cores $(2.5 \mathrm{~cm}$ in diameter by $30 \mathrm{~cm}$ in depth) taken directly in two rows of wheat in 1.8-by30-m plots, which are described later. A composite sample from each plot was sent to Western Laboratories and processed as described earlier.

Tolerance and resistance trials. Five trials at St. Anthony, ID (during 2011 and 2012), Cove, OR, and Steptoe and Cashup, WA each consisted of six replicates of each wheat entry planted into a split-plot design. Each plot consisted of four drill rows in a 1.8-by9-m area. Cultivars (described later) were randomized within each replicate (main plot) and each cultivar was split (subplots) as an adjacent nematicide-treated and a control plot, in a manner similar to that described for assessing levels of tolerance to $H$. avenae in Australia (18) and in the United States (46).

A locally fabricated no-till drill was used to plant each trial. The drill was equipped with a cone-seeder, two Gandy distributors, and four series of row openers spaced at $36 \mathrm{~cm}$. Fluted opening coulters were mounted on a front tool bar and were followed by a sweep-type deep-bander for dispensing fertilizer. A second toolbar was used to mount double-disk openers to dispense seed in line with the opening coulter and deep bander. One Gandy distributor was used to dispense fertilizer $5 \mathrm{~cm}$ below and $4 \mathrm{~cm}$ to each side of the seed row. Seed was dispensed through a cone-seeder and placed into moist soil at a 3-cm depth. Seed was planted at a density of $205 \mathrm{seed} / \mathrm{m}^{2}$.

Seed was planted with or without application of the nematicide aldicarb (Temik 15G; Bayer CropScience) at the rate of $4.2 \mathrm{~kg} / \mathrm{ha}$. Untreated controls and aldicarb treatments were in adjacent drill rows (subplots) to provide side-by-side comparisons of varietal performance in replicated treated and untreated plots (46). Aldicarb was metered from a Gandy distributor on the drill and was placed into the row with the seed. To extend the protective effect of aldicarb, the foliarly applied nematicide spirotetramat (Movento 240; Bayer CropScience) was applied to foliage at a rate of $88 \mathrm{~g} / \mathrm{ha}$ in drill rows previously treated with aldicarb, as described by Smiley et al. (48). During 2011, two applications of spirotetramat were made at 2-week intervals during June, with the first and second applications being made when plants were at Haun Growth Stages 4 and 6, respectively (Zadoks scale 15 and 17) (14). During 2012, a single application was applied at Haun Growth Stage 4. Spirotetramat was tank mixed with a spreading and penetrating adjuvant to maximize leaf uptake and systemicity, as directed on the Movento label. We used a tank mix consisting of $0.25 \%$ (vol/vol) MSO (Helena Chemical Company), a proprietary blend of methylated oils and nonionic surfactants. Spirotetramat was applied at a rate of $88 \mathrm{~g}$ a.i./ha. During 2011, the applications were made using a $\mathrm{CO}_{2}$-pressurized hand-held sprayer with four Tee Jet XR8002 flat-fan nozzles spaced at 46- $\mathrm{cm}$ intervals and operated at an application volume of 133 liters/ha and a pressure of $207 \mathrm{kPa}$. During 2012, the application was made using a tractor-mounted sprayer with two Tee Jet 11003 flat-fan nozzles spaced at $50-\mathrm{cm}$ intervals and operated at an application volume of 240 liters/ha and a pressure of $207 \mathrm{kPa}$.

Seed was treated with fungicide and insecticide at labeled rates. During 2011, seed was treated with difenoconazole plus mef- enoxam at 120 and $30 \mathrm{mg}$ a.i./kg of seed, respectively (Dividend Extreme; Syngenta Crop Protection). During 2012, seed was treated with difenoconazole, mefenoxam, ipconazole, and thiamethoxam at $180,44,15$, and $129 \mathrm{mg}$ a.i. $/ \mathrm{kg}$ of seed, respectively (Dividend Extreme + Rancona 3.8FS + Cruiser 5FS, as Cruiser Maxx Custom Blend; Pendleton Grain Growers). Weed control consisted of pre-plant glyphosate and appropriate postemergence broadleaf herbicides for the weed species of importance at each location.

Fertilizer was applied at the time of planting and was banded by the seed drill in both 2011 and 2012. The fertilizer was applied as $\mathrm{N}$ at $123 \mathrm{~kg} / \mathrm{ha}$ and formulated as a 1:1 blend of 16-20-0 and urea. During 2011, wet soil caused the fertilizer shanks to plug at Steptoe and, in that instance, fertilizer was broadcast onto the soil surface immediately prior to planting, using a rate of $\mathrm{N}$ at $200 \mathrm{~kg} / \mathrm{ha}$.

Stand quality about 1 month after planting was rated on a scale of 1 to 9 , where $1=$ no established plants and $9=$ a full and uniform plant stand throughout the plot area. Stripe rust (Puccinia striiformis f. tritici Erikss.) was controlled at Steptoe during 2011 by two foliar applications of propiconazole fungicide (Tilt; Syngenta Crop Protection; propiconazole at $21 \mathrm{~g} / \mathrm{ha}$ ). During 2012, stripe rust at St. Anthony, ID and Cashup, WA was prevented by two or three applications, respectively, of propiconazole plus trifloxystrobin (Stratego; Bayer CropScience; each active ingredient at $12 \mathrm{~g}$ a.i./ha). A late-season infestation of cereal leaf beetle (Oulema melanopus) at Cove during 2011 was suppressed by applying methomyl insecticide (Lannate LV; Dupont Crop Protection; methomyl at $0.4 \mathrm{~g} / \mathrm{ha}$ ). A late-season infestation of English grain aphid (Macrosiphum avenae) at Cashup during 2012 was suppressed by applying zeta-cypermethrin insecticide (Mustang MAX; FMC Corporation; zeta-cypermethrin at $4 \mathrm{~g} / \mathrm{ha}$ ).

Plants were removed from each plot in the five tolerance plus resistance trials to examine the incidence and severity of the classical root-knotting symptom, in which adventitious roots proliferate at points on the root axis where the nematode established a specialized feeding cell (49). Roots of 20 plants from each of six replicate plots were rated visually for incidence and severity. Incidence was calculated as the percentage of plants exhibiting at least one knotted root. The severity scale was as follows: $1=$ no evidence of damage, $2=1$ to 3 knots $/$ root system, $3=3$ to 5 knots, $4=>5$ knots and $<20 \%$ reduction in plant height or root mass, and $5=>5$ knots and $>20 \%$ reduction in plant height or root mass. Additionally, during 2012, the number of $H$. avenae swollen white females on roots was counted on five plants per plot by manually rubbing roots to dislodge the white females from washed roots. The swollen females were collected on a 60-mesh sieve, washed onto filter papers, and counted with the aid of a dissecting microscope. Cultivars were rated resistant to $H$. avenae if a plant produced fewer than three white females per root system and susceptible if there were more than three white females per root system, as previously described by Ireholm (22).

Grain yields and test weights were calculated after harvesting entire plots using a Hege plot combine (Wintersteiger Inc.) at Cove, Steptoe, and Cashup and a Wintersteiger plot combine (Wintersteiger Inc.) at St. Anthony. Postharvest nematode densities were determined as described earlier. Tolerance ratings were assigned to cultivars when a statistically significant difference for yield improvement following application of nematicides occurred among cultivars across locations each year: three locations during 2011 and two locations during 2012. Cultivars were categorized using a scale described by Smiley (45): very tolerant $(<5 \%$ yield response to nematicide), tolerant ( 5 to $10 \%)$, moderately tolerant (10 to $15 \%$ ), moderately intolerant (15 to $30 \%$ ), intolerant (30 to $50 \%$ ), or very intolerant $(>50 \%)$.

During 2011, four spring wheat cultivars were evaluated in identical experiments at St. Anthony, ID, Cove, OR, and Steptoe, WA. Control cultivars included 'Alpowa' and 'Louise', each of which was known to be susceptible to $H$. avenae. Alpowa has been a leading spring wheat cultivar in the PNW for more than a decade and Louise is now planted on twice the land area as the next lead- 
ing spring wheat cultivar in the PNW (58). Ouyen (PI691921; AUS99179) is an Australian cultivar which has the Crel gene for resistance to certain pathotypes of $H$. avenae (31), including populations of $H$. avenae in Idaho, Oregon, and Washington (53). Ouyen is resistant but intolerant to $H$. avenae Pathotype Ha13 in Australia (31) and was also intolerant in a single field trial in Oregon (52). Sönmez (CIMMYT Turkey ACC 950193) exhibits moderate resistance to $H$. filipjevi in Turkey (40) and had not been evaluated for tolerance or resistance to $H$. avenae in the PNW.

During 2012, identical trials at two locations (St. Anthony, ID and Cashup, WA) included Ouyen plus 19 cultivars of current or emerging importance to the PNW wheat industry. Grain yield and test weight were measured in all plots. Each control (non-nematicide) plot was evaluated for incidence and severity of root knotting and for production of white females. The nematicidetreated plots for five cultivars were evaluated likewise, including three cultivars that had been emphasized during 2011 (Alpowa, Louise, and Ouyen) plus 'UI Stone' and 'WB-Rockland'. UI Stone (PI660550; IDO599) was included for the more intensive evaluation, because it was reported as resistant or tolerant to cereal cyst nematode in Colorado (12). WB-Rockland (PI59487) was included after an initial pre-sampling revealed that it may be resistant to $H$. avenae.

Resistance trials. Two trials to evaluate resistance were conducted near Pullman and Colton, WA during 2011 and 2012, respectively. The trials were at locations which were heavily infested with $H$. avenae (Table 1). In 2011, 24 cultivars were evaluated, including 9 PNW cultivars, 13 entries from the International Maize and Wheat Improvement Center (CIMMYT; Ankara, Turkey), and an Iranian landrace wheat (AUS28451) that exhibits resistance to two species of Pratylenchus in the PNW (49). Forty cultivars in the 2012 Western Regional Hard and Soft Spring Wheat Nurseries were evaluated during 2012. In all, 7 entries were commercial cultivars and 33 entries were advanced breeding lines from public- and private-sector breeding programs, being considered for release as commercial cultivars. In both experiments, plots were planted with a four-row head row planter (Wintersteiger Inc.) in 1-m-long plots with $30-\mathrm{cm}$ row spacing. Two of the rows consisted of the entry and the other two rows were planted with Louise, which served as the susceptible check. The design, similar to that described by O'Brien and Fisher (34), was a randomized complete block design with eight blocks. The large number of blocks and the repetition of the susceptible check within each block was designed to minimize or eliminate effects of spatial heterogeneity of nematode density across the field, thereby preventing occurrences of falsely assigning resistant reactions that could result from disease escapes in areas of low nematode density. The susceptible check was monitored and, when white females had developed but had not yet turned brown, the plots were sampled to count numbers of white females on roots. Four or five plants were removed from the inner two rows, along with an equal number of plants of Louise from the adjacent row. During 2011, the roots were gently washed and white females were counted directly on the roots using a dissecting scope. During 2012, the white females were counted directly on the roots using a magnifier, because the soil moisture and texture were ideal and soil could be gently shaken off the roots without washing.

Statistical analyses for tolerance and resistance trials. Within individual experiments the data for grain yield, nematode density and incidence of the root knot symptom were analyzed individually using univariate analysis of variance (ANOVA), with cultivar as the main plot, nematicide treatment as the subplot, and replicates as blocks. ANOVA was performed using CoStat Statistical Software (Co-Stat v. 6.400; CoHort Software). When treatment means were significant at $\alpha<0.05$, means were separated using the Tukey's honestly significant difference test. Analyses were performed on nematode density data normalized by using the $\ln (x+1)$ transformation. Logarithmic means were back transformed into real numbers for presentation in the tables. Means of ordinate data for root knotting severity were analyzed by the Kruskal-Wallis Test. When the Pearson's $\chi^{2}$ value for the experiment was significant at $\alpha<$ 0.05 , the treatments were examined pairwise to determine which treatments differed significantly. Data for four cultivars that occurred in all three experiments during 2011 were analyzed as a split-split plot design to examine effects of experiment, cultivar, and nematicide, using location as the main plot factor, cultivar as the subplot factor, and nematicide as the sub-subplot factor. Cultivars in two trials during 2012 were analyzed similarly. Data are reported as the means and standard error of the means for trials performed during each year.

Statistical analyses for resistance trials. Data were analyzed with JMP software (SAS Institute Inc.). Counts of white females were transformed with $\log _{10}(x+1)$ for analysis and nontransformed means are presented in the figures. Wheat entry was the main plot and the replicates were blocks, which were assigned as random effects. All treatments were compared with the susceptible check (Louise) using Dunnett's test at $\alpha=0.05$.

\section{Results}

Initial nematode density for tolerance and resistance trials. All sites were infested with an economically important density of H. avenae (Table 1). Two sites during 2011 (Cove and Steptoe) also contained economically important densities of $P$. neglectus (13.6 and 2.6 nematodes/g of soil, respectively) and were not reselected for trials during 2012. Densities of stunt nematodes at each site were too low (mostly $<0.01$ nematode/g of soil) to have been of economic importance.

Plant growth and development for tolerance and resistance trials. Seedling establishment and growth were excellent at each location. There were no effects of cultivar or of nematicide treatment on stand quality 1 month after planting (data not presented). However, compared with the control treatment, during both years and, particularly, during 2011, the seedling growth rate was more rapid and resulted in larger plants and denser tillering in the nematicide treatment. Quantitative data on plant morphology and development were not collected but visual effects were dramatic at each of the three locations during 2011 (Fig. 1). Little or no visible difference in plant growth was detected for the two nematicide treatments during 2012.

Root knot symptoms in tolerance and resistance trials. The mean incidence of the root-knotting symptom in the three trials during 2011 was $100 \%$ for the four cultivars in the untreated controls and $91 \%$ in the nematicide-treated plants (Table 2$)$. The treatment effect for nematicide was significant $(\alpha<0.01)$ and, in the nematicide-added treatment, the incidence of root knotting was less $(\alpha=0.02)$ on Ouyen $(88 \%)$ than on Alpowa $(93 \%)$ and Sönmez (93\%).

During 2012, the incidence of root knotting in control plots was again at or near $100 \%$ for each cultivar (Tables 2 and 3) and differences among cultivars in the controls did not differ at $\alpha=0.05$. The nematicide treatment averaged $12 \%$ fewer $(\alpha<0.01)$ symptomatic plants than in the control treatment (Table 2). Within the nematicide treatment, Ouyen (79\%) and WB-Rockland (80\%) had fewer $(\alpha<0.01)$ symptomatic plants than Alpowa (95\%), Louise (94\%), and UI Stone (95\%).

Severity of the root-knot symptom during 2011 was high for each cultivar in the controls at each location. There were no differences in root knotting among cultivars in the controls at any location or when data were averaged across locations (Table 2). The nematicide treatment reduced the severity of root knotting $(\alpha<$ $0.01)$ at all three locations and when averaged across locations (Table 2$)$. Severity was less $(\alpha<0.01)$ in the nematicide (3.1) than in the control treatment (4.6) (Table 2). Significant differences among cultivars occurred only in the nematicide treatment at St. Anthony, where the knotting symptom was less on Louise (3.8 \pm $0.1)$ and Ouyen $(3.7 \pm 0.2)$ than on Alpowa $(4.5 \pm 1.8)$.

During 2012, the severity of root knotting differed among cultivars in the controls (Table 2 and 3) and the nematicide treatments (Table 2) at each location and when averaged across locations. Severity was less $(\alpha<0.01)$ in the nematicide (2.6) than in the 
control treatment (3.6) (Table 2). Disease severity in both the controls and nematicide treatment was least for Ouyen and WB-Rockland (Tables 2 and 3).

$H$. avenae white females in tolerance and resistance trials. Newly produced swollen white females were quantified during 2012 for five cultivars and two nematicide treatments in the trials at St. Anthony, ID and Cashup, WA (Table 2). Mean number of white females were 20 times greater $(\alpha<0.01)$ in the control than in the nematicide treatment and did not differ among cultivars in the nematicide treatment. In the control, at least $80 \%$ fewer cysts $(\alpha<0.01)$ were recovered from roots of Ouyen and WB-Rockland than from Alpowa, Louise, and UI Stone. Production of white females was also evaluated for 20 spring wheat cultivars in the control treatment. The fewest white females were produced on Ouyen and WB-Rockland (Table 3; Fig. 2). These two entries were the only cultivars that produced fewer than three white females per root system, thereby meeting our metric for resistance. Therefore, Ouyen and WB-Rockland were rated as resistant and the other 18 cultivars were considered susceptible.

Grain yield in tolerance and resistance trials. Grain yield in the controls did not differ among cultivars in the three trials conducted during 2011 (Table 2). In the nematicide treatment, Ouyen yielded less grain than Louise. Average yields of all cultivars were increased $(\alpha<0.01)$ by application of nematicides in all three trials. Mean increase from nematicide was $47 \%$ at Cove (range of 40 to $58 \%$ ), $93 \%$ at Steptoe (range of 47 to $144 \%$ ), and $25 \%$ at St. Anthony (range of 19 to $31 \%$ ). Overall, application of nematicide tended to increase the grain yield of Louise by a smaller amount than for Alpowa, Ouyen, and Sönmez (Table 2). In these trials,
Alpowa was characterized as very intolerant and the other three cultivars as intolerant.

In the controls during 2012, the yield of UI Stone was greater than for Ouyen and WB-Rockland (Table 2). Application of nematicides increased yields by an average of $9 \%(\alpha<0.01)$ and, within the nematicide treatment, the yield of WB-Rockland was less $(\alpha<0.01)$ than for the other four cultivars. Yield increases due to application of nematicide were greater for Alpowa and Ouyen than for Louise, UI Stone, and WB-Rockland. Average yields in the controls tended to be higher in $2012(3,250 \mathrm{~kg} / \mathrm{ha})$ than in 2011 $(2,734 \mathrm{~kg} / \mathrm{ha})$, and the overall increase due to application of nematicide was much less during 2012 (9\%) than during 2011 (47\%).

When yields were compared for the 20 spring wheat cultivars in the 2012 trials, WB-Rockland was among the two lowest-yielding entries in the controls and was the lowest-yielding entry in the nematicide treatment (Table 3). Highest-yielding cultivars in the control treatment included 'Alturas', 'Babe', 'Otis', 'UI Pettit', and UI Stone. Yield increase following the application of nematicides was greater than $15 \%$ for Alpowa, 'Bullseye', 'Klasic', and Otis, indicating moderate intolerance to $H$. avenae. The change in yield was less than 5\% for 'Buck Pronto' and UI Stone, leading to assignment of very tolerant ratings. Ratings of tolerant (5 to $10 \%$ yield improvement from nematicide application) were assigned to Babe, 'Cabernet', 'Glee', 'JD', 'Jedd', 'Jefferson', 'Kelse', Louise, UI Pettit, and WB-Rockland.

Postharvest density of $\boldsymbol{H}$. avenae in tolerance and resistance trials. Each year, the mean postharvest density of $H$. avenae differed $(\alpha=0.01)$ among cultivars in the control treatment but not in
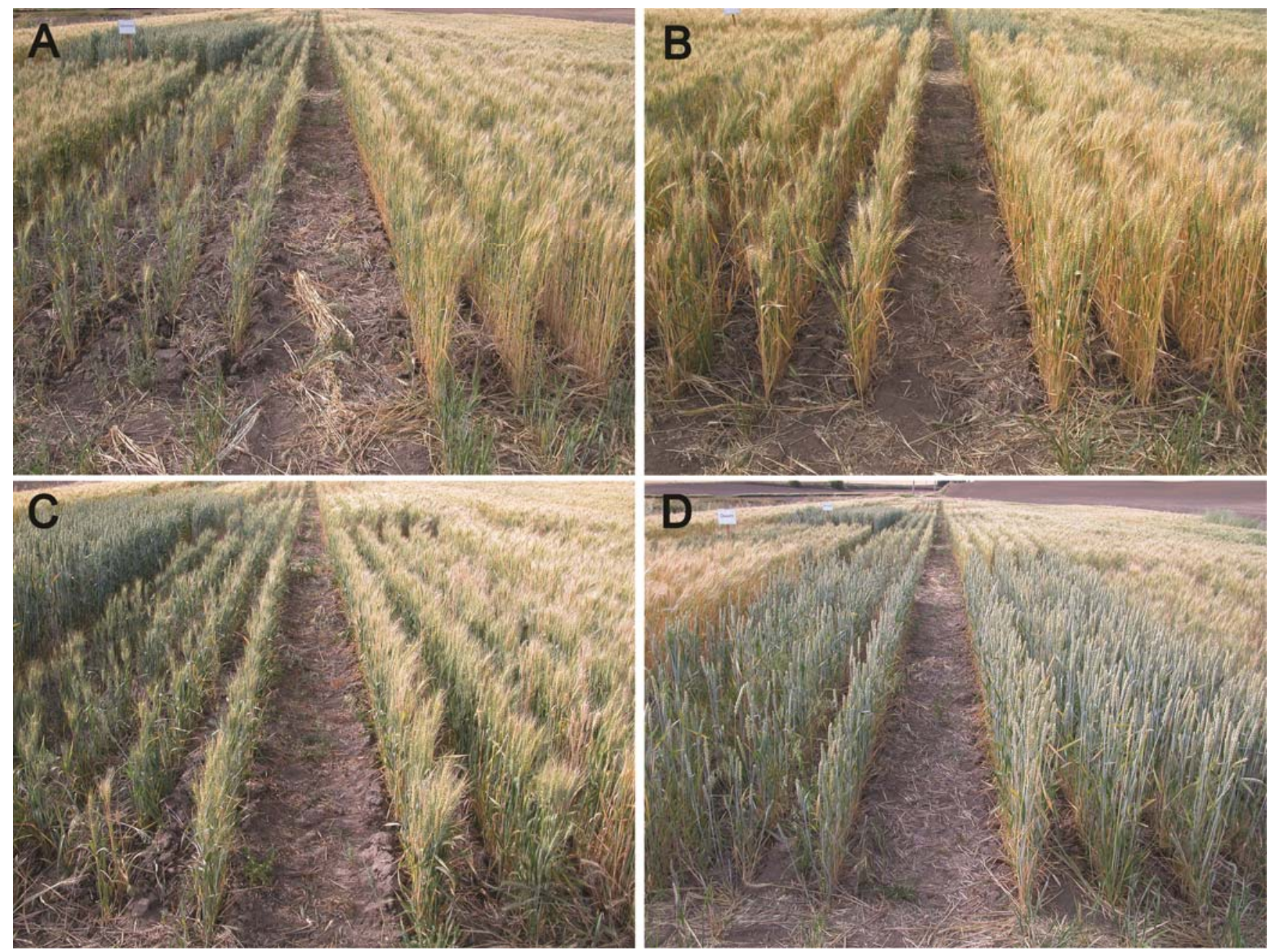

Fig. 1. Spring wheat cultivars in soil naturally infested by Heterodera avenae at Steptoe, WA on 24 August 2011: A, Alpowa; B, Louise; C, Ouyen; and D, Sönmez. The drill row on the left was not treated with nematicide and the drill row on the right was treated with the nematicides aldicarb (4.2 kg/ha) and spirotetramat ( $88 \mathrm{~g} / \mathrm{ha})$. 
the nematicide treatment (Table 2). During 2011, the nematode density was highest after Sönmez $(19,135 \pm 192)$, lowest after Ouyen $(3,751 \pm 97)$, and intermediate after production of Alpowa $(11,058 \pm 557)$ and Louise $(14,690 \pm 1,615)$. During 2012, the nematode density was highest following Alpowa $(14,592 \pm 2,887)$, Louise $(12,277 \pm 3,065)$, and UI Stone $(13,831 \pm 3,124)$ and was lowest following Ouyen $(4,151 \pm 1,360)$ and WB-Rockland $(4,961$ $\pm 1,432$ ). Application of nematicides reduced the postharvest density of $H$. avenae for all cultivars at each site; by 77 and $60 \%$ for the means of three susceptible cultivars during 2011 and 2012, respectively, and by $42 \%$ for Ouyen during 2011 and $12 \%$ for the mean of Ouyen and Rockland during 2012, respectively. Because the nematode did not effectively multiply on Ouyen during 2012, it was presumed that was also true during 2011. If so, it appears that the base density of eggs remaining from older cysts produced on previous crops was between 2,000 and 4,000 eggs/ $\mathrm{kg}$ of soil during 2011 and between 3,000 and 6,000 eggs/ $\mathrm{kg}$ during 2012, corresponding to densities found following production of nematicidetreated cultivars and of untreated Ouyen during 2011 and of untreated Ouyen and WB-Rockland during 2012. There was not a significant $(P>0.05)$ cultivar-nematicide interaction at any of these five locations.

Resistance trials. During 2011, only Ouyen and Chara, both of which contain the Crel resistance gene, were rated as resistant (Fig. 3) because they had less than three swollen white females per root system and also significantly $(\alpha<0.05)$ fewer white females than the susceptible check Louise. Cultivars carrying the $\mathrm{Cre} 7$ and Cre 8 genes were susceptible to the $H$. avenae population at this location in Washington. The most susceptible entry in this trial ('Sunco') produced $8.0 \pm 2.1$ white females per root system. In
2012, the advanced breeding lines SY-97621-05 and UC1711 were identified as resistant in that they produced an average of less than one white female per plant (Fig. 4). Two other lines (SO900163 and SY-B041418) also had less than three white females per root system and significantly fewer white females than Louise; means and standard errors of the means for these three cultivars were 2.0 $\pm 3.5,1.8 \pm 3.6$, and $7.4 \pm 3.5$ females/root system, respectively. Alpowa, ARS03171LS-12, 'Hank', IDO862T, KW070559, and SO900230 had significantly more white females than Louise. The most susceptible entry in this trial (ARS03171LS-12) produced $11.5 \pm 3.6$ white females per root system.

\section{Discussion}

An objective of this research was to evaluate tolerance and resistance to nematodes in fields naturally infested by $H$. avenae in the PNW states of Idaho, Oregon, and Washington. We initially compared two widely grown but susceptible PNW-adapted cultivars (Alpowa and Louise) with two exotic cultivars (Ouyen and Sönmez) that had been shown, under controlled conditions, to be resistant to either $H$. avenae (53) or H. filipjevi (40). As expected, during 2011, we confirmed that both Alpowa and Louise were good hosts for multiplication of $H$. avenae. Louise was more tolerant than Alpowa, in that yield improvement due to application of nematicide was always greater for Alpowa than for Louise. This was the first demonstration in the PNW that commercial spring wheat cultivars differ in tolerance to $H$. avenae.

Ouyen was examined because it had been found under controlled conditions to be resistant to $H$. avenae populations examined in the PNW (53). We confirmed that Ouyen is highly resistant but also found it to be intolerant to $H$. avenae in PNW fields, as

Table 2. Evaluation of tolerance and resistance of six spring wheat cultivars in fields infested by Heterodera avenae, in plots treated or not treated with nematicides in 2011 (three experiments) and 2012 (two experiments) ${ }^{t}$

\begin{tabular}{|c|c|c|c|c|c|c|c|c|c|c|c|c|}
\hline \multirow[b]{2}{*}{ Year, cultivar } & \multicolumn{2}{|c|}{$\mathbf{R K}$ incid $(\%)^{\mathbf{u}}$} & \multicolumn{2}{|c|}{ RK sever (1-5) } & \multicolumn{2}{|c|}{ White females/plant ${ }^{v}$} & \multicolumn{3}{|c|}{ Grain yield (kg/ha) } & \multicolumn{2}{|c|}{$\begin{array}{l}\text { Postharvest density of } \\
\text { H. avenae } / \mathrm{kg} \text { of soil }{ }^{\mathrm{w}}\end{array}$} & \multirow[b]{2}{*}{$\mathbf{P R}^{\mathbf{Z}}$} \\
\hline & Control & Treated $^{\mathrm{x}}$ & Control & Treated & Control & Treated & Control & Treated & $\%$ incr. $^{\mathbf{y}}$ & Control & Treated & \\
\hline \multicolumn{13}{|l|}{2011} \\
\hline Alpowa & $100 \pm 0$ & $93.1 \pm 2.5 \mathrm{a}$ & $4.6 \pm 0.1$ & $3.4 \pm 0.3$ & nd & nd & $2,530 \pm 277$ & $4,155 \pm 256 \mathrm{ab}$ & 64 & $11,058 \pm 557 \mathrm{~b}$ & $3,461 \pm 216$ & VI \\
\hline Louise & $100 \pm 0$ & $90.8 \pm 3.2 \mathrm{ab}$ & $4.5 \pm 0.1$ & $2.9 \pm 0.2$ & nd & nd & $3,163 \pm 223$ & $4,258 \pm 138 \mathrm{a}$ & 35 & $14,690 \pm 1,615 \mathrm{ab}$ & $4,035 \pm 804$ & I \\
\hline Ouyen & $100 \pm 0$ & $88.3 \pm 3.6 \mathrm{~b}$ & $4.6 \pm 0.1$ & $2.9 \pm 0.2$ & nd & nd & $2,502 \pm 208$ & $3,621 \pm 169 b$ & 45 & $3,751 \pm 97 \mathrm{c}$ & $2,192 \pm 113$ & I \\
\hline Sönmez & $100 \pm 0$ & $93.3 \pm 2.8 \mathrm{a}$ & $4.7 \pm 0.1$ & $3.3 \pm 0.2$ & nd & nd & $2,741 \pm 199$ & $4,038 \pm 192 \mathrm{ab}$ & 47 & $19,135 \pm 1,432 \mathrm{a}$ & $2,641 \pm 658$ & I \\
\hline Mean & 100 & 91.4 & 4.6 & 3.1 & nd & nd & 2,734 & 4,018 & 47 & 12,159 & 3,582 & $\ldots$ \\
\hline $\mathrm{HSD}_{0.05}$ & ns & 3.2 & $\ldots$ & $\ldots$ & $\cdots$ & $\ldots$ & ns & 438 & $\ldots$ & 6,785 & $\mathrm{~ns}$ & $\cdots$ \\
\hline$P>F$ & $\ldots$ & 0.02 & 0.20 & 0.19 & $\ldots$ & $\ldots$ & 0.07 & 0.03 & $\ldots$ & 0.01 & 0.17 & $\cdots$ \\
\hline \multicolumn{13}{|l|}{2012} \\
\hline Alpowa & $100 \pm 0$ & $95 \pm 3$ a & $4.0 \pm 0.1 \mathrm{a}$ & $2.7 \pm 0.1 \mathrm{ab}$ & $10.6 \pm 1.6 \mathrm{a}$ & $0.3 \pm 0.4$ & $3,267 \pm 513 a b c$ & $3,880 \pm 548 \mathrm{a}$ & 19 & $14,592 \pm 2887 \mathrm{a}$ & $6,496 \pm 2,530$ & $\mathrm{MI} / \mathrm{S}$ \\
\hline Louise & $100 \pm 0$ & $94 \pm 2 \mathrm{a}$ & $3.9 \pm 0.1 \mathrm{a}$ & $2.7 \pm 0.1 \mathrm{ab}$ & $6.7 \pm 1.2 \mathrm{a}$ & $0.7 \pm 1.2$ & $3,373 \pm 429 a b$ & $3,576 \pm 483 \mathrm{a}$ & 6 & $12,277 \pm 3065 \mathrm{ab}$ & $5,335 \pm 1,921$ & $\mathrm{~T} / \mathrm{S}$ \\
\hline Ouyen & $98 \pm 2$ & $79 \pm 6 \mathrm{~b}$ & $3.0 \pm 0.2 \mathrm{~b}$ & $2.3 \pm 0.1 \mathrm{~b}$ & $0.6 \pm 0.7 \mathrm{~b}$ & $0.1 \pm 0.2$ & $3,098 \pm 390 \mathrm{bc}$ & $3,436 \pm 468 \mathrm{a}$ & 11 & $4,151 \pm 1360 \mathrm{c}$ & $4,301 \pm 1,692$ & $\mathrm{MT} / \mathrm{R}$ \\
\hline UI Stone & $100 \pm 0$ & $95 \pm 5 \mathrm{a}$ & $4.1 \pm 0.1 \mathrm{a}$ & $2.9 \pm 0.1 \mathrm{a}$ & $10.5 \pm 2.1 \mathrm{a}$ & $0.3 \pm 0.4$ & $3,837 \pm 576 \mathrm{a}$ & $3,961 \pm 579 \mathrm{a}$ & 3 & $13,831 \pm 3124 \mathrm{a}$ & $4,620 \pm 1,424$ & $\mathrm{VT} / \mathrm{S}$ \\
\hline WB-Rockland & $100 \pm 0$ & $80 \pm 7 b$ & $3.0 \pm 0.1 \mathrm{~b}$ & $2.4 \pm 0.1 \mathrm{~b}$ & $1.1 \pm 1.1 \mathrm{~b}$ & $0.2 \pm 0.8$ & $2,674 \pm 314 \mathrm{c}$ & $2,795 \pm 357 \mathrm{~b}$ & 5 & $4,961 \pm 1432 \mathrm{bc}$ & $3,676 \pm 1,491$ & $\mathrm{~T} / \mathrm{R}$ \\
\hline Mean & 100 & 88 & 3.6 & 2.6 & 5.9 & 0.3 & 3,250 & 3,530 & 9 & 9,962 & 4,886 & $\ldots$ \\
\hline $\mathrm{HSD}_{0.05}$ & ns & 7 & $\ldots$ & & 10.4 & ns & 428 & 373 & $\ldots$ & 5,610 & $\mathrm{~ns}$ & $\ldots$ \\
\hline$P>F$ & 0.20 & $<0.01$ & $<0.01$ & $<0.01$ & $<0.01$ & 0.19 & $<0.01$ & $<0.01$ & $\ldots$ & $<0.01$ & 0.27 & $\ldots$ \\
\hline
\end{tabular}

${ }^{t}$ Experiments during 2011 were at St. Anthony, ID, Cove, OR, and Steptoe, WA; and, during 2012, were at St. Anthony, ID and Cashup, WA. Means plus standard error (six replicates per experiment) are reported in the table for $2011(n=18)$ and $2012(n=12)$. Within years, the means for grain yield, nematode density, and incidence of root knot symptoms followed by the same letter within a column did not differ significantly at $\alpha=0.05$ as determined by Tukey's honestly significant difference (HSD) test for a split-split plot design; ns $=$ not significant. Nematode densities were analyzed as the $\ln (x+1)$ transformation; therefore, the HSD is not shown for the back transformed means where there are significant differences among cultivars. Means of severity data for the root knot symptom were analyzed by the Kruskal-Wallis Test. When the Pearson's $\chi^{2}$ value for the experiment was significant at $\alpha<0.05$, treatments were examined pairwise to determine which treatments differed significantly.

${ }^{\mathrm{u}} \mathrm{RK}$ incid = percentage of plants with the root knotting symptom on at least one root. RK sever $=$ severity rating scaled as $1=$ no evidence of damage, $2=1$ to 3 knots/root system, $3=3$ to 5 knots, $4=>5$ knots and $<20 \%$ reduction in plant height or root mass, and $5=>5$ knots and $>20 \%$ reduction in plant height or root mass.

${ }^{v}$ Number of white females per plant, back-transformed means from analyses performed using the $\ln (x+1)$ transformation; nd = not determined.

w Postharvest density of eggs plus juveniles, from cysts; counts during 2011 were restricted to two locations (Cove OR and St. Anthony ID) due to inexplicable and very low apparent counts reported for all samples collected and processed from Steptoe, WA.

${ }^{\mathrm{x}}$ Nematicide treatment included application of aldicarb $(4.2 \mathrm{~kg} / \mathrm{ha}$ ) in the seed row at the time of planting and two (during 2011) or one (during 2012) foliar application of spirotetramat ( $88 \mathrm{~g} / \mathrm{ha}$ ) at 1 month after planting; in 2011, the second application was made 2 weeks following the first application.

y Percentage increase in grain yield due to application of nematicides. All increases were significant at $\alpha<0.05$.

${ }^{\mathrm{z}} \mathrm{PR}$ indicates phenotypic assignments for tolerance and resistance reactions. Tolerance ratings were VT $=$ very tolerant $(<5 \%$ yield response to nematicide), $\mathrm{T}=$ tolerant $(5$ to $10 \%), \mathrm{MT}=$ moderately tolerant $(10$ to $15 \%), \mathrm{MI}=$ moderately intolerant $(15$ to $30 \%), \mathrm{I}=$ intolerant $(30$ to $50 \%)$, or $\mathrm{VI}=$ very intolerant $(>50 \%)$. Cultivars were designated resistant $(\mathrm{R})$ or susceptible (S) if root systems had fewer or more than three white females, respectively. 
was demonstrated in all six trials in which Ouyen was entered during 2011 and 2012. Ouyen was derived from the parentage Takari/TM56//Cocamba (http://wheatpedigree.net/sort/renderPedi gree/51749). The pedigrees for both 'TM56' and 'Cocamba' are similar: AUS10894/4* Condor. AUS10894 contains the single dominant Crel gene for resistance to $H$. avenae $(36,43)$ (http://wheatpedigree.net/sort/ renderPedigree/15032). AUS10894 was shown to be resistant to populations of $H$. avenae in Australia (17,34), Europe (33), and the PNW (53). Ouyen and AUS10894 were each previously described as resistant but intolerant to populations of $H$. avenae in Australia $(18,31)$.

Chara was as resistant as Ouyen in the only trial where Chara was tested. Chara (AUS30031; V1341R) is an Australian hard white spring wheat that, like Ouyen, contains the Crel gene and exhibits strong resistance to Australian populations of $H$. avenae but is intolerant of invasion by $H$. avenae (http://www.seednet. com.au/NR/rdonlyres/B7239645-223E-414D-AF81-540504AEF 2E6/0/FSChara.pdf). Chara was derived from a cross of 'BD225' and 'CD87' (http://wheatpedigree.net/sort/renderPedigree/15032). BD225 has the pedigree Cook*2/Millewa/TM56. As stated for Ouyen, the pedigree of TM56 includes the Crel gene donor AUS10894.

During 2012, we identified a high level of resistance and tolerance to $H$. avenae in WB-Rockland. This is the first known report of a North American commercial spring wheat cultivar that exhibits resistance to $H$. avenae. The nature of the resistance we discovered in WB-Rockland is not fully understood. WB-Rockland was derived as pedigree Expresso/2*Solano (http://wheatpedigree. net/sort/renderPedigree/80458) using marker-assisted selection by
Westbred LLC to transfer resistance genes for P. striiformis from 'Expresso' (PI651616) into a Solano (PI644067) background. The stripe rust genes in Expresso had been derived from six backcrosses using 'Express' (PI573003) as the recurring parent and the two gene donors, 'Avocet' (PI464644) and 'Madsen' (PI511673). The Expresso pedigree (Express 6*/YR15 Avocet// Express 6*/Madsen; DA984-034SRR) was derived by crosses and markerassisted selection by Dr. Jorge Dubcovsky, University of California at Davis. Madsen has the pedigree VPM/Moisson 951/2/2*Hill 81 (http://wheatpedigree.net/sort/renderPedigree/ 42621). 'Moisson' (PI315998) is susceptible to $H$. avenae (23) but Madsen inherited moderately high resistance to eyespot (Oculimacula spp.; formerly Pseudocercosporella herpotrichoides), stripe rust (Puccinia striiformis), stem rust ( $P$. recondita), and leaf rust ( $P$. graminis) from VPM1 $(9,56)$.

VPM1 is a French bread wheat breeding line possessing two translocations from Aegilops ventricosa Tausch, one between the short arm of A. ventricosa 2 NS and Triticum aestivum 2AS, including the three rust resistance genes $\operatorname{Lr} 37, \mathrm{Yr} 17$, and $\mathrm{Sr} 38$ conferring resistance to leaf rust ( $P$. triticina Erikss.), stripe rust ( $P$. striiformis f. tritici Erikss.), and stem rust (P. graminis f. sp. tritici Erikss. \& Henning), respectively, and the other between A. ventricosa 7NS and T. aestivum chromosome 7DL, which contains Pch1 conferring resistance to eyespot $(9,30)$. The $H$. avenae resistance gene $C r e 5$ is closely linked to the $Y R 17 / \operatorname{Lr} 37 / \operatorname{Sr} 38$ cluster of resistance genes (23) (http://wheatpedigree.net/sort/show/ 79672). Madsen contains this cluster of rust resistance genes (3) and was shown to exhibit resistance to $H$. filipjevi in China (29). Akar et al. (1) and Çalişkan et al. (11) found the Crel resistance gene for H. avenae to be

Table 3. Evaluation of 20 spring wheat cultivars for tolerance and resistance to Heterodera avenae in two Idaho and Washington fields during 2012, treated or not treated with nematicides ${ }^{\mathrm{u}}$

\begin{tabular}{|c|c|c|c|c|c|c|c|}
\hline \multirow[b]{2}{*}{ Cultivar } & \multirow[b]{2}{*}{ Market class $^{\mathbf{v}}$} & \multirow[b]{2}{*}{ RK severity $(1-5)^{w}$} & \multirow[b]{2}{*}{ Females/plant ${ }^{x}$} & \multicolumn{3}{|c|}{ Grain yield (kg/ha) } & \multirow[b]{2}{*}{$\mathbf{P R}^{\mathbf{z}}$} \\
\hline & & & & Control & Treated & Increase $(\%)^{y}$ & \\
\hline Alpowa & SW & $4.1 \pm 0.1 \mathrm{a}$ & $11.9 \pm 3.5 \mathrm{~b}-\mathrm{k}$ & $3,267 \pm 513 \mathrm{a}-\mathrm{d}$ & $3,880 \pm 548 \mathrm{a}-\mathrm{d}$ & 19 & $\mathrm{MI} / \mathrm{S}$ \\
\hline Alturas & SW & $4.1 \pm 0.1 \mathrm{a}$ & $9.2 \pm 3.7 \mathrm{e}-\mathrm{n}$ & $3,585 \pm 586 \mathrm{a}-\mathrm{c}$ & $4,031 \pm 667 \mathrm{ab}$ & 12 & $\mathrm{MT} / \mathrm{S}$ \\
\hline Babe & SW & $4.0 \pm 0.1 \mathrm{a}$ & $18.3 \pm 7.1 \mathrm{bc}$ & $3,687 \pm 526 \mathrm{ab}$ & $3,923 \pm 550 \mathrm{a}-\mathrm{d}$ & 6 & $\mathrm{~T} / \mathrm{S}$ \\
\hline Buck Pronto & $\mathrm{HR}$ & $3.7 \pm 0.2 \mathrm{a}-\mathrm{c}$ & $13.4 \pm 5.5 \mathrm{~b}-\mathrm{i}$ & $3,004 \pm 400 \mathrm{~cd}$ & $3,137 \pm 446 \mathrm{f}-\mathrm{h}$ & 4 & $\mathrm{VT} / \mathrm{S}$ \\
\hline Bullseye & HR & $4.0 \pm 0.2 \mathrm{a}$ & $9.9 \pm 4.0 \mathrm{~d}-\mathrm{m}$ & $3,093 \pm 461 \mathrm{~b}-\mathrm{d}$ & $3,675 \pm 499 a-f$ & 19 & $\mathrm{MI} / \mathrm{S}$ \\
\hline Cabernet & HR & $3.8 \pm 0.2 \mathrm{ab}$ & $9.2 \pm 4.8 \mathrm{e}-\mathrm{n}$ & $3,044 \pm 433 \mathrm{~cd}$ & $3,309 \pm 410 \mathrm{e}-\mathrm{h}$ & 9 & $\mathrm{~T} / \mathrm{S}$ \\
\hline Glee & $\mathrm{HR}$ & $4.0 \pm 0.1 \mathrm{ab}$ & $17.9 \pm 8.9 \mathrm{~b}-\mathrm{e}$ & $3,390 \pm 420 \mathrm{a}-\mathrm{c}$ & $3,623 \pm 458 \mathrm{a}-\mathrm{g}$ & 7 & $\mathrm{~T} / \mathrm{S}$ \\
\hline JD & SW club & $3.7 \pm 0.2 \mathrm{a}-\mathrm{c}$ & $8.8 \pm 3.8 \mathrm{e}-\mathrm{n}$ & $3,204 \pm 443 b-d$ & $3,489 \pm 500 \mathrm{~b}-\mathrm{g}$ & 9 & $\mathrm{~T} / \mathrm{S}$ \\
\hline Jedd & $\mathrm{HR}$ & $4.0 \pm 0.1 \mathrm{ab}$ & $11.9 \pm 3.3 \mathrm{~b}-\mathrm{k}$ & $3,041 \pm 364 \mathrm{~cd}$ & $3,277 \pm 415 \mathrm{e}-\mathrm{h}$ & 8 & $\mathrm{~T} / \mathrm{S}$ \\
\hline Jefferson & HR & $4.1 \pm 0.1 \mathrm{a}$ & $28.9 \pm 10.3 \mathrm{a}$ & $3,355 \pm 355 \mathrm{a}-\mathrm{c}$ & $3,564 \pm 548 \mathrm{a}-\mathrm{g}$ & 6 & $\mathrm{~T} / \mathrm{S}$ \\
\hline Kelse & HR & $3.9 \pm 0.1 \mathrm{ab}$ & $16.9 \pm 4.4 \mathrm{~b}-\mathrm{e}$ & $3,001 \pm 453 \mathrm{~cd}$ & $3,248 \pm 490 \mathrm{f}-\mathrm{h}$ & 8 & $\mathrm{~T} / \mathrm{S}$ \\
\hline Klasic & HW & $4.0 \pm 0.1 \mathrm{a}$ & $7.9 \pm 2.8 \mathrm{f}-\mathrm{n}$ & $2,656 \pm 443 d$ & $3,125 \pm 435 \mathrm{gh}$ & 18 & $\mathrm{MI} / \mathrm{S}$ \\
\hline Louise & SW & $4.1 \pm 0.1 \mathrm{a}$ & $10.2 \pm 4.7 \mathrm{c}-1$ & $3,373 \pm 429 \mathrm{a}-\mathrm{c}$ & $3,576 \pm 483 \mathrm{a}-\mathrm{g}$ & 6 & $\mathrm{~T} / \mathrm{S}$ \\
\hline Otis & HW & $4.0 \pm 0.1 \mathrm{a}$ & $14.0 \pm 7.4 \mathrm{~b}-\mathrm{h}$ & $3,504 \pm 492 \mathrm{a}-\mathrm{c}$ & $4,090 \pm 557 \mathrm{a}$ & 17 & $\mathrm{MI} / \mathrm{S}$ \\
\hline Ouyen & ASW & $3.2 \pm 0.3 \mathrm{c}$ & $1.4 \pm 1.0 \mathrm{n}$ & $3,098 \pm 390 b-d$ & $3,436 \pm 468 \mathrm{c}-\mathrm{g}$ & 11 & $\mathrm{MT} / \mathrm{R}$ \\
\hline UI Pettit & SW & $3.8 \pm 0.3 \mathrm{ab}$ & $12.3 \pm 4.4 \mathrm{~b}-\mathrm{j}$ & $3,477 \pm 453 \mathrm{a}-\mathrm{c}$ & $3,804 \pm 509$ a-e & 9 & $\mathrm{~T} / \mathrm{S}$ \\
\hline UI Stone & SW & $4.1 \pm 0.1 \mathrm{a}$ & $19.9 \pm 9.3 b$ & $3,837 \pm 576 a$ & $3,961 \pm 579 \mathrm{a}-\mathrm{c}$ & 3 & $\mathrm{VT} / \mathrm{S}$ \\
\hline WB $1035 \mathrm{Cl}+$ & SW & $4.0 \pm 0.2 \mathrm{a}$ & $15.2 \pm 5.1 \mathrm{c}-\mathrm{g}$ & $3,188 \pm 483 b-d$ & $3,539 \pm 505 b-g$ & 11 & $\mathrm{MT} / \mathrm{S}$ \\
\hline WB-Rockland & HR & $3.3 \pm 0.1 \mathrm{bc}$ & $1.2 \pm 0.7 \mathrm{n}$ & $2,674 \pm 314 d$ & $2,795 \pm 357 \mathrm{~h}$ & 5 & $\mathrm{~T} / \mathrm{R}$ \\
\hline Westbred 936 & HR & $4.1 \pm 0.1 \mathrm{a}$ & $16.2 \pm 4.8 \mathrm{~b}-\mathrm{f}$ & $3,050 \pm 489 \mathrm{~cd}$ & $3,404 \pm 556 \mathrm{~d}-\mathrm{g}$ & 12 & $\mathrm{MT} / \mathrm{S}$ \\
\hline Mean & $\ldots$ & 3.9 & 12.7 & 3,226 & 3,544 & 10 & $\ldots$ \\
\hline$P>F$ & $\ldots$ & $<0.0001$ & $<0.0231$ & $<0.0001$ & $<0.0001$ & $\ldots$ & $\ldots$ \\
\hline $\mathrm{HSD}_{0.05}$ & $\ldots$ & $\ldots$ & 8.3 & 347 & 299 & $\ldots$ & $\ldots$ \\
\hline
\end{tabular}

u Nematicide treatment included application of aldicarb $(4.2 \mathrm{~kg} / \mathrm{ha})$ in the seed row at the time of planting and one foliar application of spirotetramat $(88$ $\mathrm{g} / \mathrm{ha})$ at 1 month after planting. Mean values for six replications at two locations $(n=12)$ and the standard error are presented in the table. Means followed by the same letter within a column did not differ significantly at $\alpha=0.05$ as determined by Tukey's honestly significant difference (HSD) test. Means of severity data for the root knot symptom were analyzed by the Kruskal-Wallis test and, when the Pearson's $\chi^{2}$ value for the experiment was significant at $\alpha$ $<0.05$, cultivars were examined pairwise to determine which treatments differed significantly.

${ }^{v}$ Market classes of spring wheat: $\mathrm{HR}=$ hard red, $\mathrm{HW}=$ hard white, $\mathrm{SW}=$ soft white, Club = soft white club. ASW refers to the Australian market class Australian Standard White.

${ }^{\mathrm{w}}$ Root knotting severity rating scaled as $1=$ no evidence of damage, $2=1$ to 3 knots/root system, $3=3$ to 5 knots, $4=>5$ knots and $<20 \%$ reduction in plant height or root mass, and $5=>5$ knots and $>20 \%$ reduction in plant height or root mass. More than $98 \%$ of all cultivars exhibited the root knotting symptom on at least one root(e.g., the incidence was 98 to $100 \%$ ).

${ }^{x}$ Number of white females per plant; means of three replications at two locations $(n=6)$ and standard error.

y Percentage increase in grain yield due to application of nematicides; all were significant at $\alpha<0.05$.

${ }^{\mathrm{z}} \mathrm{PR}$ indicates phenotypic assignments for tolerance and resistance reactions. Tolerance ratings were VT $=$ very tolerant $(<5 \%$ yield response to nematicide), $\mathrm{T}=$ tolerant $(5$ to $10 \%), \mathrm{MT}=$ moderately tolerant $(10$ to $15 \%), \mathrm{MI}=$ moderately intolerant $(15$ to $30 \%), \mathrm{I}=$ intolerant $(30$ to $50 \%)$, or $\mathrm{VI}=$ very intolerant $(>50 \%)$. Cultivars were designated resistant $(\mathrm{R})$ or susceptible $(\mathrm{S})$ if root systems had fewer or more than three white females, respectively. 
effective against populations of $H$. filipjevi in Turkey. Smiley et al. (53) demonstrated that the Crel and CreR genes provided excellent resistance to PNW populations of $\mathrm{H}$. avenae; that the $\mathrm{Cre} 5$, Cre 7 , and $\mathrm{Cre} 8$ genes provided moderate resistance; and that the $\mathrm{Cre} 2$ and $\mathrm{Cre} 3$ genes were ineffective. The $H$. avenae resistance gene Cre 2 was also derived from A. ventricosa and incorporated into the introgression line H-93-8 (16). It appears possible that resistance to $H$. avenae in WB-Rockland reflects an inheritance of Cre5 resistance derived from Madsen, and that expression of $\mathrm{Cre} 5$ resistance under field conditions is greater than we observed in controlled-environment tests. Additional studies using a molecular probe that detects the Cre5 gene (60) will be required to examine our hypothesis.

Although WB-Rockland was among the lower-yielding cultivars in trials reported here, it was the fifth-highest-yielding cultivar in an identical trial performed on an irrigated $H$. avenae-infested field located very close $(1 \mathrm{~km})$ to the trial at St. Anthony, ID during 2012; the yield of WB-Rockland was $5,677 \mathrm{~kg} / \mathrm{ha}$ compared with the overall trial mean of $5,207 \mathrm{~kg} / \mathrm{h}$ a for the 20 cultivars reported in this article. Data from the irrigated trial were not reported in this article because 80 of the 240 plots, including variable numbers of plots and treatments from each replicate, failed to receive supplemental water from the circle irrigation system, thereby causing great variation across the data set. Nevertheless, all nematode resistance and tolerance data trends from plots that were either rainfed or received supplemental irrigation in that third trial during 2012 were similar and complimentary to those we report from the two rainfed trials during 2012.

Resistance trials during 2012 identified four advanced breeding lines from the 2012 Western Regional Hard and Soft Spring Wheat Nurseries that exhibited useful to excellent levels of resistance to H. avenae. SY-97621-05 and UC1711 were identified as highly resistant and SO900163 and SY-B041418 appeared to exhibit useful levels of resistance that are worthy of further examination. The two SY lines were submitted for testing in the regional nursery by the AgriPro cereal improvement program, which is a component of Syngenta Cereals, Berthoud, CO. The pedigree of SY-97621-05 is $\mathrm{B} 95-0136$ (ANB/5/EREN/RAP/3/JAR//SON/KLRE/4/MAB/6/

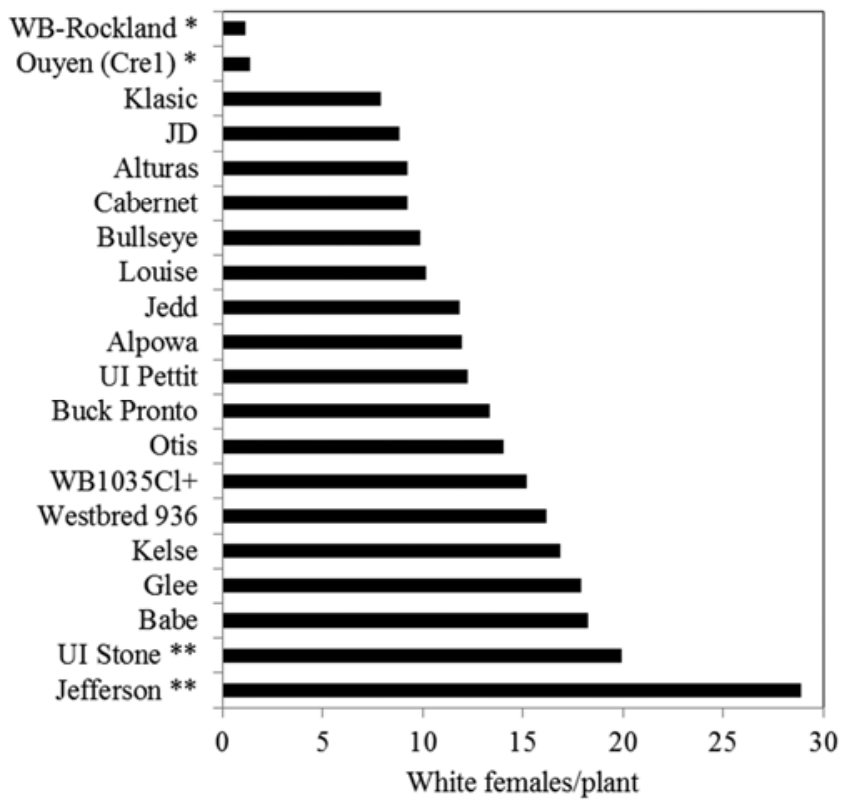

Fig. 2. Number of Heterodera avenae white swollen females produced on 20 spring wheat cultivars ('Ouyen' + 19 Pacific Northwest cultivars) tested during 2012 in two experiments near St. Anthony, ID and Cashup, WA; means of three replicates in each of two trials. Cultivars indicated with * are significantly less than the spring wheat check 'Louise' and cultivars indicated with ** are significantly greater than the check Louise according to analysis of variance performed on transformed data $(\ln [x$ $+1]$ ) at $\alpha<0.05$. The presence of a 'Cre' gene for resistance to certain pathotypes of $H$. avenae is indicated, if known.
BOMB/LNI)/SCAB23-1(THB/SEP7780//SUZG/WEAVER//NING $8675)$. The pedigree of SY-B041418 is BMTC/BBIG. The pedigree of $\mathrm{UC} 1711$ is $\mathrm{UC1357/Kern}+2 \mathrm{~N}^{\mathrm{v} S}$ translocation and was developed by the University of California at Davis. The pedigree of UC1357 is MAY-NAC/[(JILGUERO'S' $\times($ D6301×NAI60)) $] \times$ Yecora Rojo. The pedigree of SO900163 is WA7985/Zak Yr5+Yr15 (SRZ05116)//SRW05554 from Washington State University. The nature and origin of $H$. avenae resistance in all four breeding lines is unknown but UC1711 likely carries the $2 \mathrm{~N}^{\mathrm{v} S}$ translocation containing Cre5. SO900163 does not contain the $2 \mathrm{~N}^{\mathrm{v}} \mathrm{S}$ translocation based on molecular marker analysis with the VENTRIUP-LN2 marker. These lines are being examined with markers associated with previously identified resistance genes, in the manner described for screening germplasm for the presence of Crel and Cre3 (37) or of Cre1, Cre3, Cre5, Cre8, and CreY (2).

Sönmez (CIMMYT Turkey ACC 950193) is a cultivar that exhibits moderate resistance to $H$. filipjevi in Turkey (40) and had not been evaluated for tolerance or resistance to $H$. avenae in the PNW. In our field trials during 2011, Sönmez failed to reduce the postharvest density of $H$. avenae at three locations and was also intolerant of $H$. avenae. Testing of Sönmez was curtailed because it did not appear to be a useful resource for improving wheat tolerance or resistance to $H$. avenae in the PNW. However, because some fields in Oregon are infested by both $H$. filipjevi and $H$. avenae (61), Sönmez may become a useful resource for further evaluation in regions where both species occur.

To examine tolerance and resistance, we used two approaches for evaluating the influence of cultivars on the postharvest density of $H$. avenae. First, the nematode density was compared for untreated plots planted to either the resistant Ouyen or to a susceptible cultivar such as Alpowa or Louise. Second, the nematode density was compared with plots of a resistant entry that was either treated or not treated with nematicides. In all cases, the postharvest density of $H$. avenae was roughly equivalent in untreated plots of

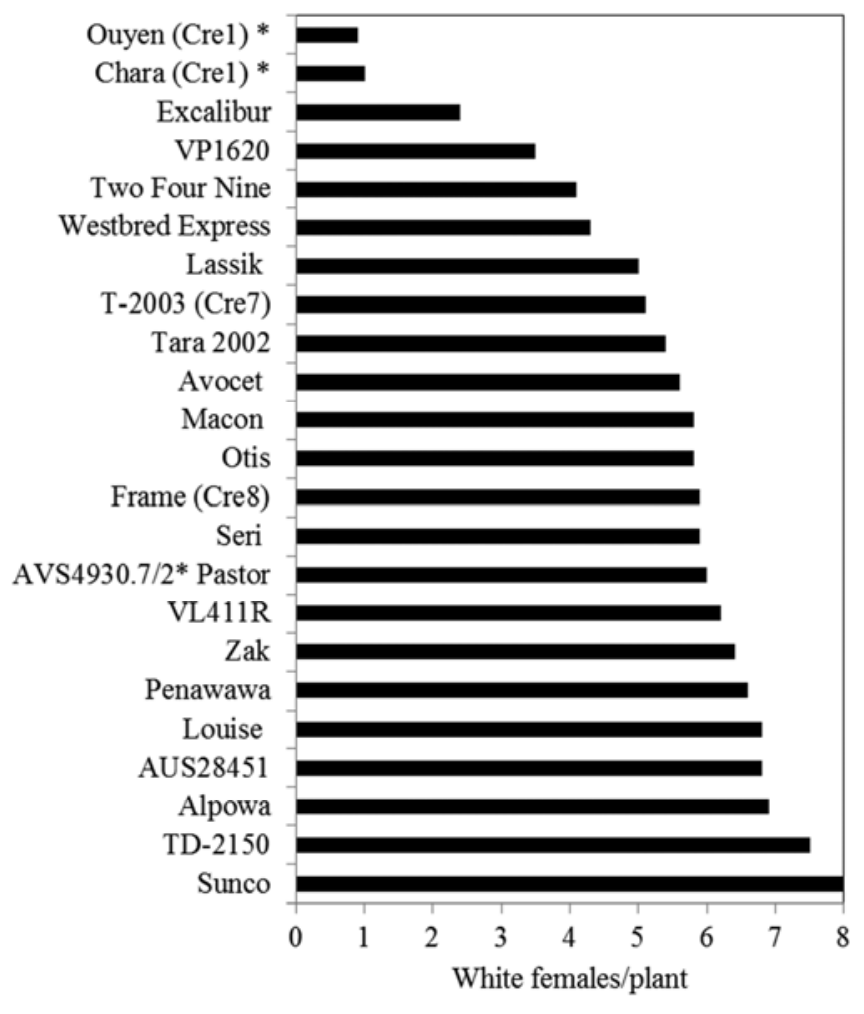

Fig. 3. Number of Heterodera avenae white swollen females produced on 24 wheat cultivars, lines, or landraces tested near Pullman, WA during 2011; means of eight replicates, each of which was paired with the spring wheat check 'Louise'. Entries indicated with * are significantly less than the check Louise according to Dunnett's test performed on transformed data $\left(\log _{10}[x+1]\right)$ at $\alpha<0.05$. The presence of a 'Cre' gene for resistance to certain pathotypes of $H$. avenae is indicated, if known. 
Ouyen or WB-Rockland to what appeared to be the natural background remaining from eggs retained in cysts produced by previous crops. The apparent background density was assumed to be similar to the nematode density in nematicide-treated plots that were also planted to a resistant cultivar. Only a portion of $H$. avenae eggs hatch from cysts during a single season (5). Of the eggs remaining within cysts, an average of about $60 \%$ hatch to produce the invasive juvenile stage each year (5). However, the actual hatching rate can vary from 40 to $90 \%$ per year (4). Therefore, hatching from individual cysts is spread over many years. Andersson (6) stated that protection of spring wheat from economic damage required the $H$. avenae density to be reduced to less than one egg per gram of soil. We did not achieve that goal by producing a resistant spring wheat cultivar during a single year. It will require multiple years with repetitive use of a resistant cultivar to achieve that goal, as was described by Rivoal et al. (39). Nevertheless, we report here the first evidence that $\mathrm{Crel}$ resistance to $\mathrm{H}$. avenae is fully expressed in naturally infested field environments in the PNW.

Although Ouyen and WB-Rockland were resistant to $H$. avenae, it was also clearly evident in the control treatments that the incidence of root knotting on these resistant cultivars was no different than for susceptible cultivars. This should be of no surprise because the second-stage juveniles penetrate epidermal cells behind

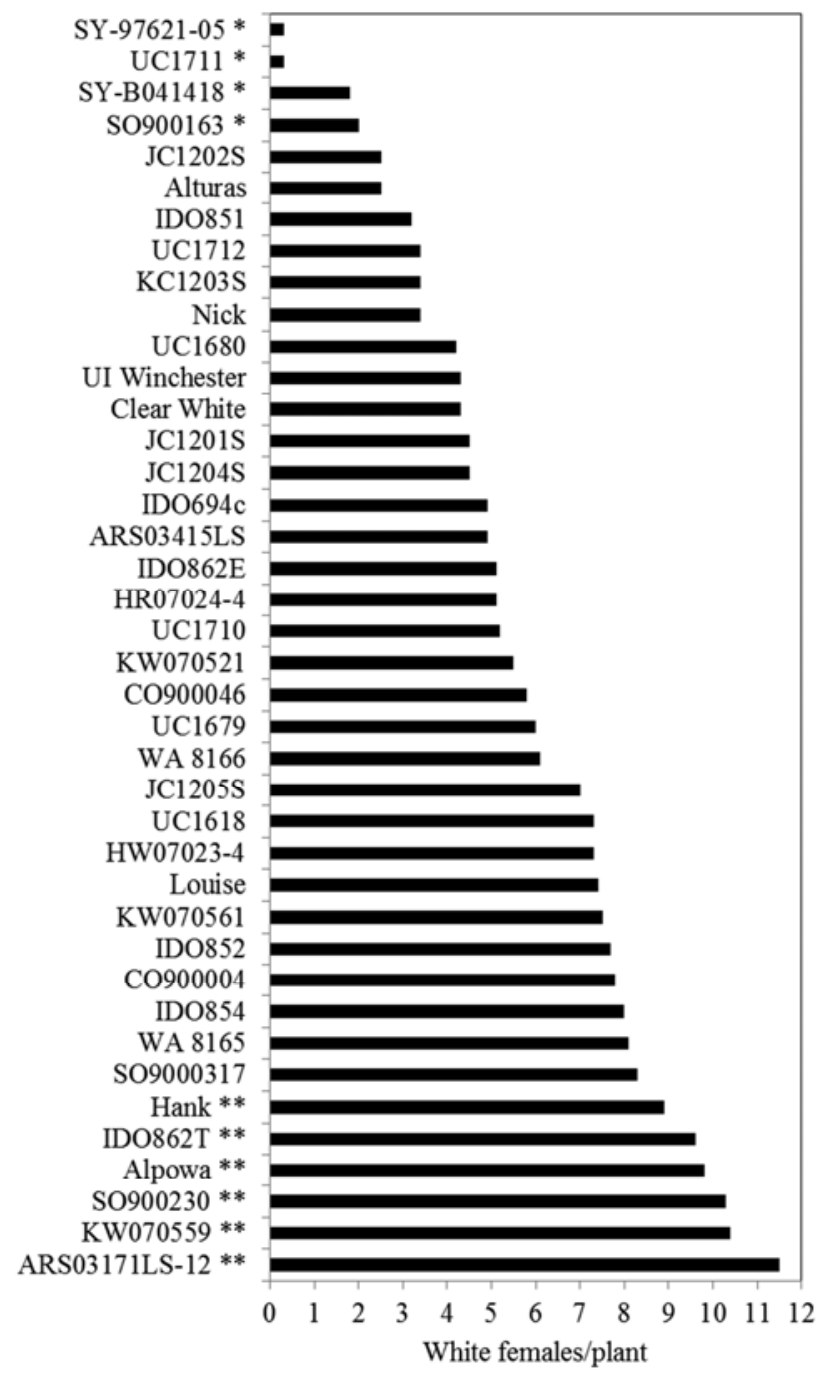

Fig. 4. Number of Heterodera avenae white swollen females produced on 40 spring wheat cultivars tested in an experiment near Colton, WA during 2012; means of eight replicates, each of which was paired with the check 'Louise'. Cultivars indicated with * are significantly less than the check Louise and cultivars indicated with ${ }^{* *}$ are significantly greater than the check Louise according to Dunnett's test performed on transformed data $\left(\log _{10}[x+1]\right)$ at $\alpha<0.05$. the root cap and move intracellularly to the growth zone (8). The juveniles successfully penetrate roots in equal numbers for resistant as well as susceptible cultivars $(35,38)$. After a succession of molts, the females reprogram root cells to induce the formation of specialized feeding cells (21). Cells of the syncytium develop but then quickly deteriorate in resistant cultivars, causing death or suppressed reproductive capacity of the female associated with the deteriorated syncytium $(7,42)$. Resistance is expressed by a reduced ability of the nematode to produce viable eggs. Therefore, resistant cultivars may reduce the density of $H$. avenae in soil but may still be sensitive to earlier root injury that leads to a reduction of plant growth and grain production. Similar results with Alpowa were reported for suppression of egg production by foliar application of spirotetramat (48). The nematode penetrated and damaged the root before the nematicide could suppress production of eggs. Egg production was suppressed by spirotetramat treatment but yield of the susceptible, intolerant Alpowa was not improved. In the current study, we report that Ouyen and WB-Rockland are each resistant to $H$. avenae but are either moderately tolerant or tolerant, respectively. It can be anticipated that repetitive plantings of resistant cultivars will reduce the $H$. avenae density over time, thereby reducing the risk to a subsequent planting of a susceptible cultivar.

The most profitable cultivar for commercial use in the PNW will likely be a cultivar that combines resistance and tolerance to $H$. avenae, as has been advocated elsewhere $(18,35)$. Results of field trials reported here demonstrated consistently that the PNWadapted Louise was more tolerant than Ouyen. Also, we found that the high-yielding UI Stone was very tolerant but susceptible to $H$. avenae. These results clarify an earlier report (12) that UI Stone performed well in eastern Colorado under high pressure from cereal cyst nematode, leading the authors to conclude that UI Stone "may have resistance or tolerance to CCN." A white wheat cultivar combining favorable characteristics of the white wheats Louise and Ouyen, or of UI Stone and Ouyen, would likely become more accepted into commercial agriculture than a resistant but intolerant cultivar such as Ouyen. Likewise, a cross between a very tolerant but susceptible hard red wheat cultivar such as Buck Pronto and the resistant but tolerant and lower-yielding hard red wheat cultivar WB-Rockland is suggested.

Aldicarb has been a long-favored research tool for examining effects of plant-parasitic nematodes on spring wheat $(10,20,45$, $52,57)$. Aldicarb is often applied with the seed at planting time to suppress damage and reproduction of nematodes. This nematicide has a half-life up to 5 weeks, reduces the Heterodera population early in the plant growth period, and results in improved grain yields for genotypes that are intolerant to the nematode. Aldicarb is widely used to identify effects of nematodes or insect pests because it does not suppress effects of fungal root pathogens $(27,28)$. In contrast, in eastern Oregon fields infested by H. avenae, aldicarb sometimes failed to improve grain yield in response to disease trading, where root injury from the nematode was reduced and the severity of Pythium root rot and Rhizoctonia root rot were increased (47). Aldicarb had no influence on growth or yield of spring wheat in another eastern Oregon field where densities of plant-parasitic nematodes were very low (50).

Spirotetramat was recently introduced as the first broad-spectrum insecticide that exhibits both phloem and xylem mobility (ambimobile) and, therefore, is translocated throughout the plant (59). The hydrolysis product of spirotetramat reduces fecundity (number of eggs deposited) and fertility (viability of eggs produced) when ingested orally by immature life stages of sucking insects. Incomplete edysis (shedding of the cuticle during molting) has also been observed in aphid populations, leading to immobility and subsequent death of affected individuals (32). Foliar applications of spirotetramat have reduced the postharvest density of $H$. avenae in naturally infested wheat fields (48). The use of spirotetramat in this study was as a foliar application to drill strips that were previously treated with aldicarb at the time of planting. Our goal was to prolong the prophylactic activity of nematicides over a 
longer period of the growing season because juveniles of $H$. avenae hatch at different times during the spring and can survive in soil and remain invasive to roots for as long as 7 weeks $(15,26)$. In this study, it was clearly evident that the combination of these nematicides provided sufficient suppression of nematode reproduction and of root injury to enable us to differentiate tolerance levels among a selection of wheat cultivars and lines. These nematicides continue to be critical research tools for identifying differences in tolerance and resistance of wheat cultivars to plant-parasitic nematodes such as $H$. avenae. Future emphasis on management of $H$. avenae in the PNW should be placed on developing genotypes with both tolerance and resistance, and on refining the understanding of effects of crop rotations.

\section{Acknowledgments}

We thank the Idaho Wheat Commission, Oregon Wheat Commission, Washington Wheat Commission, Idaho Agricultural Experiment Station, Oregon Agricultural Experiment Station, and USDA-ARS Root Disease and Biological Control Unit (at Pullman, WA) for funding; K. Rhinhart, P. Thorgersen, M. Chandler, A. Hitzman, E. Hannuf, S. Isbell, and N. Webster (Oregon State University), T. Shelman and K. Bissonnette (University of Idaho), and S. Johnson, J. Kuehner, Y. Manning, and G. Shelton (Washington State University) for technical assistance; Mid-Columbia Producers (Wasco, OR), Westbred LLC (Bozeman, MT), and Whitgro Inc. (St. John, WA) for donations of wheat seed; Pendleton Grain Growers (Pendleton, OR) for donations of seed treatments; Western Laboratories (Parma, ID) for providing discounted nematode testing fees; D. Daw (St. Anthony, ID), S. Johnson (Cove, OR), D. Morgan (Colfax, WA), A. Schultheis (Colton, WA), M. Fulfs and J. Bauer (Pullman, WA), and J. Scholz (Steptoe, WA) for land and crop management assistance; and L. Ellis (University of Idaho), D. Walenta (Oregon State University), and S. Van Vleet (Washington State University) for coordinating field tours at experimental sites.

\section{Literature Cited}

1. Akar, T., Çalişkan, M., Nicol, J. M., Uranbey, S., Sahin, E., Yazar, S., William, M, and Braun, H. J. 2009. Molecular characterization of cereal cyst nematode diagnostic markers $\mathrm{Crel}$ and $\mathrm{Cre} 3$ in some winter wheat germplasm and their potential use against Heterodera filipjevi. Field Crops Res. 114:320-323.

2. Al-Doss, A, A., Al-Hazmi, A. S., Dawabah, A. A. M., Abdel-Mawgood, A. A., Al-Rehiayani, S. M., Al-Otayk, S., Moustafa, K. A., and Motawei, M. I. 2010. Impact of Cre and peroxidase genes of selected new wheat lines on cereal cyst nematode (Heterodera avenae Woll.) resistance. Aust. J. Crop Sci. 4:737-743.

3. Allan, R. E., Peterson, C. J., Rubenthaler, G. L., Line, R. F., and Roberts, D. E. 1989. Registration of Madsen wheat. Crop Sci. 29:1575.

4. Andersen, K., and Andersen, S. 1970. [Decrease of cereal cyst nematode infestation after growing resistant barley cultivars of grasses]. Tidsskr. Planteavl. 74:559-565.

5. Andersen, S. 1961. Resistens mod Havreål Heterodera avenae. Copenhagen, Denmark, Meddelelse. Konelige. Vet. Landbrugets Plantekult. No. 68.

6. Andersson, S. 1982. Population dynamics and control of Heterodera avenae - a review with some original results. EPPO Bull. 12:463-475.

7. Andres, M. F., Melillo, M. T., Delibes, A., Romero, M. D., and BleveZacheo, T. 2001. Changes in wheat root enzymes correlated with resistance to cereal cyst nematodes. New Phytol. 152:343-354.

8. Baldwin, J. G., and Mundo-Ocampo, M. 1991. Heteroderinae, cyst- and non-cyst-forming nematodes. Pages 275-362 in: Manual of Agricultural Nematology. W. R. Nickle, ed. Marcel Dekker, New York.

9. Bariana, H. S., and McIntosh, R. A. 1993. Cytogenetic studies in wheat XV. Location of rust resistance genes in VPM1 and their genetic linkage with other disease resistance genes in chromosome 2A. Genome 36:476-482.

10. Brown, R. H. 1987. Control strategies in low-value crops. Pages 351-387 in: R. H. Brown and B. R. Kerry, eds. Principles and Practice of Nematode Control in Crops. Academic Press, Sydney, Australia

11. Çalişkan, M., Uranbey, S., Nicol, J., Akar, T., Elekçioğlu, H., and Kaya, G. 2011. Indirect selection of $\mathrm{Crel}$ gene in winter wheat populations. Arch. Biol. Sci. Belgrade 63:49-53.

12. Chen, J., Wheeler, J., Clayton, J., Zhao, W., O'Brien, K., Jackson, C., and Marshall, J. M. 2013. Release of 'UI Stone' soft white spring wheat. J. Plant Regist. vol. 7. In press

13. Cook, R., and Evans, K. 1987. Resistance and tolerance. Pages 179-231 in: Principles and Practice of Nematode Control in Crops. R. H. Brown and B. R. Kerry, eds. Academic Press, Sydney, Australia

14. Cook, R. J., and Veseth, R. J. 1991. Wheat Health Management. American Phytopathological Society, St. Paul, MN.

15. Davies, K. A., and Fisher, J. M. 1976. Duration of infectivity of second stage larvae of Heterodera avenae. Nematologica 22:163-168.

16. Delibes, A., Romero, D., Aguaded, S., Duce, A., Mena, M., Lopez-Braña, I., Andrés, M.-F., Martin-Sanchez, J.-A., and García-Olmedo, F. 1993. Resistance to the cereal cyst nematode (Heterodera avenae Woll.) transferred from the wild grass Aegilops ventricosa to hexaploid wheat by a "stepping stone" procedure. Theor. Appl. Genet. 87:402-408.

17. Eastwood, R. F., Lagudah, E. S., Appels, R., Hannah, M., and Killmorgen, J. F. 1991. Triticum tauschii: a novel source of resistance to cereal cyst nematode (Heterodera avenae). Aust. J. Agric. Res. 42:69-77.

18. Fisher, J. M. 1982. Problems with the use of resistance in wheat to the Australian pathotypes of Heterodera avenae. EPPO Bull. 12:417-421.

19. Hafez, S. I., Golden, A. M., Rashid, R., and Handoo, Z. 1992. Plant-parasitic nematodes associated with crops in Idaho and eastern Oregon. Nematropica 22:193-204.

20. Hague, N. G. M., and Gowen, S. G. 1987. Chemical control of nematodes. Pages 131-178 in: Principles and Practice of Nematode Control in Crops. R. H. Brown and B. R. Kerry, eds. Academic Press, Sydney, Australia.

21. Hewezi, T., Maier, T. R., Nettleton, D., and Baum, T. J. 2012. The Arabidopsis microRNA396-GRF1/GRF3 regulatory module acts as a developmental regulator in the reprogramming of root cells during cyst nematode infection. Plant Physiol. 159:321-335.

22. Ireholm, A. 1994. Characterization of pathotypes of cereal cyst nematodes, Heterodera spp., in Sweden. Nematologica 4:399-411.

23. Jahier, J., Abelard, P., Tanguy, A. M., Dedryver, F., Rivoal, R., Khatkar, S., and Bariana, H. S. 2001. The Aegilops ventricosa segment on chromosome 2AS of the wheat cultivar 'VPM1' carries the cereal cyst nematode resistance gene Cre5. Plant Breed. 120:125-128.

24. Jensen, H. J., Eshtiaghi, H., Koepsell, P. A., and Goetze, N. 1975. The oat cyst nematode, Heterodera avenae, occurs in oats in Oregon. Plant Dis. Rep. 59:1-3.

25. Kandel, S. L. 2012. A survey of root lesion and cereal cyst nematodes in the dryland wheat production areas of eastern Washington and resistance of $\mathrm{Pa}$ cific Northwest wheat varieties. MS thesis, Washington State University, Pullman.

26. Kerry, B. R., and Jenkinson, S. C. 1976. Observations on emergence, survival and root invasion of second-stage larvae of the cereal cyst nematode, Heterodera avenae. Nematologica 22:467-474.

27. Kimpinski, J., and Johnson, H. W. 1995. Effects of aldicarb and fungicides on Pratylenchus penetrans populations, root rot and net blotch severity on barley. Phytoprotection 76:9-16

28. Kimpinski, J., Johnson, H. W., and Martin, R. A. 1987. Influence of aldicarb on root lesion nematodes, leaf disease and root rot in wheat and barley. Plant Pathol. 36:333-338.

29. Li, H., Cui, L., Li, H., Wang, X., Murray, T. D., Conner, R. L., Wang, L., Gao, X., Sun, Y., Sun, S., and Tang, W. 2012. Effective resources in wheat and wheat-Thinopyrum derivatives for resistance to Heterodera filipjevi in China. Crop Sci. 52:1209-1217.

30. Maia, N. 1967. Obtention de blés tendres resistants au pietin-verse par croisements interspécifiques blés $\times$ Aegilops. C. R. Hebd. Séances Acad. Agric. Fr. 53:149-154.

31. Martin, P. J. 1994. Triticum aestivum ssp. vulgare (bread wheat) cv. Ouyen. Aust. J. Exp. Agric. 34:863.

32. Nauen, R., Reckmann, J., Thomzik, J., and Thielert, W. 2008. Biological profile of spirotetramat (Movento) — a new two-way systemic (ambimobile) insecticide against sucking pest species. Bayer CropSci. J. 61:245-278.

33. Nielsen, C. H. 1982. Heredity of Heterodera avenae resistance originating from two barley cultivars and one spring wheat cultivar. EPPO Bull. $12: 457-461$.

34. O'Brien, P.C., and Fisher, J.M. 1974. Resistance within wheat, barley and oat cultivars to Heterodera avenae in South Australia. Aust. J. Exp. Agric. Anim. Husb. 14:399-404.

35. O'Brien, P. C., and Fisher, J. M. 1977. Development of Heterodera avenae on resistant wheat and barley cultivars. Nematologica 23:390-397.

36. O'Brien, P. C., Fisher, J. M., and Rathjen, A. J. 1980. Inheritance of resistance in two wheat cultivars to an Australian population of Heterodera avenae. Nematologica 26:69-74.

37. Ogbonnaya, F. C., Subrahmanyam, N. C., Moullet, O., de Majnik, J., Eagles, H. A., Brown, J. S., Eastwood, R. F., Kollmorgan, J., Appels, R., and Lagudah, E. S. 2001. Diagnostic DNA markers for cereal cyst nematode resistance in bread wheat. Aust. J. Agric. Res. 52:1367-1374.

38. Rivoal, R., Doussinault, G., and Hullé, M. 1990. Influence of Heterodera avenae on winter wheat in France; experiments with resistant and susceptible varieties. Ann. Appl. Biol. 116:537-548.

39. Rivoal, R., Lasserre, F., and Cook, R. 1995. Consequences of long-term cropping with resistant cultivars on the population dynamics of the endoparasitic nematodes Heterodera avenae and Pratylenchus neglectus in a cereal production ecosystem. Nematologica 41:516-529.

40. Sağlam, H. D., Cobanoğlu, S., Wesemael, W., Nicol, J. M., Viaene, N., and Dababat, A. A. 2009. Preliminary investigation of resistance in winter wheat to Heterodera filipjevi under controlled conditions. Pages 172-176 in: Cereal Cyst Nematodes: Status, Research and Outlook. I. T. Riley, J. M. Nicol, and A. A. Dababat, eds. CIMMYT, Ankara, Turkey.

41. Schillinger, W. R., Papendick, R. I., Guy, S. O., Rasmussen, P. E., and Kessel, C. van. 2006. Dryland cropping systems in the western United States. Pages 365-393 in: Dryland Agriculture, 2nd ed. G. A. Peterson, P. W. Unger, and W. A. Payne, eds. Agron. Monogr. 23. American Society of Agronomy, Madison, WI

42. Seah, S., Miller, C., Sivasithamparam, K., and Lagudah, E. S. 2000. Root responses to cereal cyst nematode (Heterodera avenae) in hosts with differ- 
ent resistance genes. New Phytol. 146:527-533.

43. Slootmaker, L. A. J., Lange, W., Jochemsen, G., and Schepers, J. 1974. Monosomic analysis in bread wheat of resistance to cereal root eelworm. Euphytica 23:497-503.7

44. Smiley, R. W. 2009. Occurrence, distribution and control of Heterodera avenae and $H$. filipjevi in the western USA. Pages 35-40 in: Cereal Cyst Nematodes: Status, Research and Outlook. I. T. Riley, J. M. Nicol, and A. A. Dababat, eds. CIMMYT, Ankara, Turkey.

45. Smiley, R. W. 2009. Root-lesion nematodes reduce yield of intolerant wheat and barley. Agron. J. 101:1322-1335.

46. Smiley, R. W., Gourlie, J. A., Rhinhart, K. E. L., Marshall, J. M., Anderson, M. D., and Yan, G. P. 2012. Influence of nematicides and fungicides on spring wheat in fields infested with soilborne pathogens. Plant Dis. 96:1537-1547.

47. Smiley, R. W., Ingham, R. E., Uddin, W., and Cook, G. H. 1994. Crop sequences for managing cereal cyst nematode and fungal populations of winter wheat. Plant Dis. 78:1142-1149.

48. Smiley, R. W., Marshall, J. M., and Yan, G. P. 2011. Effect of foliarly applied spirotetramat on reproduction of Heterodera avenae on wheat roots. Plant Dis. 95:983-989.

49. Smiley, R. W., and Nicol, J. M. 2009. Nematodes which challenge global wheat production. Pages 171-187 in: Wheat Science and Trade. B. F. Carver, ed. Wiley-Blackwell, Ames, IA.

50. Smiley, R. W., Whittaker, R. G., Gourlie, J. A., and Easley, S. A. 2005. Pratylenchus thornei associated with reduced wheat yield in Oregon. J. Nematol. 37:45-54.

51. Smiley, R. W., Whittaker, R. G., Gourlie, J. A., and Easley, S. A. 2006. Geocenamus brevidens associated with reduced yield of no-till annual spring wheat in Oregon. Plant Dis. 90:885-890.

52. Smiley, R. W., Whittaker, R. G., Gourlie, J. A., Easley, S. A., and Ingham, R. E. 2005. Plant-parasitic nematodes associated with reduced wheat yield in Oregon: Heterodera avenae. J. Nematol. 37:297-307.

53. Smiley, R. W., Yan, G. P., and Pinkerton, J. N. 2011. Resistance of wheat, barley and oat to Heterodera avenae in the Pacific Northwest USA. Nematology 13:539-552.

54. Stanton, J. M., and Fisher, J. M. 1988. Factors of early growth associated with tolerance of wheat to Heterodera avenae. Nematologica 34:188-197.

55. Strausbaugh, C. A., Bradley, C. A., Koehn, A. C., and Forster, R. L. 2004 Survey of root diseases of wheat and barley in southeastern Idaho. Can. J. Plant Pathol. 26:167-176.

56. Strausbaugh, C. A., and Murray, T. D. 1989. Inheritance of resistance to Pseudocercosporella herpotrichoides in three cultivars of winter wheat Phytopathology 79:1048-1053.

57. Taylor, S. P., Vanstone, V. A., Ware, A. H., McKay, A. C. Szot, D., and Russ, M. H. 1999. Measuring yield loss in cereals caused by root lesion nematodes (Pratylenchus neglectus and P. thornei) with and without nematicides. Aust. J. Agric. Res. 50:617-622.

58. [USDA-NASS] United States Department of Agriculture National Agricultural Statistics Service. 2011. http://www.nass.usda.gov

59. Vermeer, R., and Baur, P. 2008. Movento product development: custommade formulations for an exceptional active ingredient. Bayer CropSci. J. 61:141-158

60. Williams, K. J., Willsmore, K. L., Olson, S., Matic, M., and Kuchel, H. 2006. Mapping a novel QTL for resistance to cereal cyst nematode in wheat. Theor. Appl. Genet. 112:1480-1486.

61. Yan, G. P., and Smiley, R. W. 2010. Distinguishing Heterodera filipjevi and $H$. avenae using polymerase chain reaction-restriction fragment length polymorphism and cyst morphology. Phytopathology 100:216-224.

62. Yan, G. P., Smiley, R. W., and Okubara, P. A. 2012. Detection and quantification of Pratylenchus thornei in DNA extracted from soil using real-time PCR. Phytopathology 102:14-22.

63. Yan, G. P., Smiley, R. W., Okubara, P. A., Skantar, A., Easley, S. A., Sheedy, J. G., and Thompson, A. L. 2008. Detection and discrimination of Pratylenchus neglectus and $P$. thornei in DNA extracts from soil. Plant Dis. 92:1480-1487. 